\title{
制振材料を用いた床衛撃音低減に関する研究 その4：コンクリートスラブを用いた制振特性の検討
}

山本耕三，塩田正純，山口道征，小林真人 119

福島寬和 [建設省建築研究所第 5 研究部防煙研究室 室長・工博] 本報は, 重量床衝撃音遮断性能の向上を目的とした制振材料利用 の床工法に関する開発研究の第 4 報である。本報では, 拘束型制振材 料の施工の有無によるコンクリートスラブの振動特性を詳細に検討 している。一般的に振動系は, 質量 (慣性), 抵抗 (減衰性), バネ (剛性)の 3 つの要素でモデル化できる。従来の重量床衝撃音に関す る研究では, 林構造の質量と剛性に着目することが多く, 減衰特性 を詳細に検討した研究事例は少なかったように思われる。床の工法 や施工方法などにより減衰特性が大きく変化すること, また減衰特 性の計測が難しいこと等がその要因と思われる。しかし, 後者の問 題については, 近年の信号処理技術の飛躍的向上により, 短時間に 比較的精度良く計測できるようになってきている。筆者らも，デジ タル信号処理の応用計測法を駆使して, コンクリートスラブの振動 減衰特性を詳細に検討している。重要なテーマゆ之今後も研究体制 を維持して，精力的な検討を継続していただきたいと思う次第であ る。
橋本典久 [八戸工業大学建築工学科 教授 ·工博] 制振材によるRCスラブの床衝撃音低減効果に関する実験検討で あり，類例のない貴重な報告と評価される。ただし効果に関しては， 筆者ら自身が述べているように，スペクトル分析結果の比較だけで はなくオクターブバンドでの評価が必須であろう。一次共振周波数 でのスペクトルレベルの効果についても, 今回の試験体は, 版厚・ 大きさ・境界条件などが厳密には実際の現場の床スラブとは差があ ク，下室空間の音響条件も通常の室とは異なるため，実際にどの程 度効果が期待できるかはこの結果だけでは明確ではない。また，施 工性，費用，工期への影響などを総合した場合に，他の方法と較べ ても十分なパフォーマンスが得られるかどうかの検討も必要であろ う。しかし，このような新規性のある多くの試みが床衝撃音のよう な困難な課題のブレイクスルーには不可久であり，本来の目的であ る制振材利用のための基礎デ一夕蓄積ともども, 今後の進展を大い に期待したい。

\section{能動制御手法を用いた壁体透過音低減の検討 ースピーカを用いた壁面の 2 次放射音低減一}

古江嘉弘 [福山大学工学部建築学科 教授・工博] 本研究は，木造枠組工法による音源室と受音室が，軽量二重壁を 間仕切壁として隣接した建物を対象として, 中心周波数 $63 \mathrm{~Hz}$ の帯 域雑音を放射する 1 次音源による間仕切壁の振動加速度を, 同じく 音源室に設置した 2 次音源を用いて制御することにより，受音室へ の透過音低減の可能性を調査したものである。

2 次音源として, 1 次音源の単純な逆位相出力を用いる方法と間仕 切壁面に設置したエラーセンサーーを利用した能動制御システムによ り演算された信号を用いる方法とについて，両室内の音圧レベル分 布，間仕切壁の振動加速度分布を詳細に測定し，いずれもかなりの 低減効果が期待できることを確認している。

間仕切壁の制振手段として，機珹的制振ではなく，スピ一カから の放射音を利用するという意欲的な試みであるが, 同時に，1 次音源 による音源室内の音場への 2 次音源による影響が問題になることも 予想される。実用化に向けた今後の発展が期待される。
上明戸 昇, 角張 勲, 寺井賢一, 山下恭弘 123

尾本 章 [九州芸術工科大学芸術工学部音響設計学科 助教授・博士 (工学) $]$

本報告で紹介されている壁面を透過する低周波音の制御は, 能動 制御の適用事例としては比較的新しい領域である。筆者らは 2 種類 の制御方法を試みており，いずれも音源室内の騒音源の近くに制御 用の 2 次音源を設置している。結果として,より大きな効果を得るた めには音源をダイポール構成にして放射パワーの低減を図るより も，エラーセンサーを壁面に設置して2 次音源信号に直接的に制振 の効果を持たせる方が良いことが示されている。今後対象をオ一 ディオ機器からの再生音とするならば，ステレオに対応した複数音 源の場合にどのように効果を得るか, といった物理的問題と同時に, 付加音源の設置が音源室内での聴感上の印象に与之る影響も慎重に 考慮されていくべきであろう。たとえば音楽聴取時に付加的なス ピーカーが鳴れば音色や定位は変化する。将来的には主観的な意味 も含めた性能評価が行われることが必要となるであろう。
安岡博人 [三井建設 (株) 技術研究所 第 3 研究部長] 筆者が述べているように，空間性能として床衝撃音を測定する場 合, 代表点選定の問題は精度と直結している。また周波数デー夕を $\mathrm{dB}$ (A) で置き換える検討も測定時間短縮の要素の1つである。

ここでは大型スラブ系の実測データに基づき， L 数と $\mathrm{dB}(\mathrm{A})$ の 比較を行っている。軽量については $\mathrm{dB}(\mathrm{A})$ 測定時の暗騒音の混入 などに注意すれば，両者は比較的近似したデータとなることが，寒 測值からも伺える。重量に関しては他の検討と比べ大型スラブの傾 向が出ているか検討して欲しい。測定点数の検討を行う場合, 空間 性能の母集団をどの程度から始めるかが問題である。䘮間平均とし て 5 点の平均は, 高さ方向も含めるとまだ少ないと考之る。耳の移動 範囲内で一打点ごとに 100 点程度の受音点によるデータを最大母集 団として出発する必要もあるのではなかろうか。精度に言及する場 合，表示や保証に用いる場合と現場での品質管理に用いる場合では 必要精度も異なるであろう。今後の検討を期待する。
橋本典久 [八戸工業大学建築工学科 教授・工博] 新製品開発や品質改善などの研究目的の測定と，製品検査のため の測定では自ずとその方法，考え方が異なって然るべきである。後 者はなるべく手軽に多数の測定が行之, かつ安定的な精度が期待で きることが本来の主旨に沿うことになる。著者らが述べるように， 床衝撃音に関する性能表示制度が導入されれば製品検査的測定が増 大することが予想され, 測定に多大な労力と時間を要する現在の測 定法の簡便化は早急に整備すべき課題と言える。本報告は, 大型ス ラブを对象として，簡易測定法のうち $\mathrm{L}$ 等級の代用としての $\mathrm{L}_{\mathrm{A}}$ 利 用の可能性, および現測定法の打撃点, 測定点の減少の可能性を検 討したもので，上記の意味から貴重な事例報告として評価される。 ただし，時間的な制約からは現測定法の簡易化検討は最重要のひと つの方ではあるものの, 製品検查本来の観点から新たな测定法を 提案する方向の検討も併せて期待したい。 